\title{
Education 4.0 and Teachers: Challenges, Risks and Benefits
}

\section{ESJ Social Sciences}

\section{George A. Panagiotopolos}

Department of Museology,

University of Patras, Greece

\section{Zoe A. Karanikola}

Department of Museology,

University of Patras, Greece

Submitted: 19 October 2020

Accepted: 07 December 2020

Published: 31 December 2020

Corresponding author:

Zoe A. Karanikola

DOI: 10.19044/esj.2020.v16n34p114

(c)

Copyright 2020 Panagiotopolos G.A. \& Karanikola A.Z. Distributed under Creative Commons BY-NC-ND 4.0 OPEN ACCESS

\section{Abstract}

The aim of the present study is to investigate and capture teachers' attitudes towards the principles, benefits and risks of Education 4.0, as it is shaped in the context of the 4th Industrial Revolution. The methodology followed is the quantitative one and specifically an improvised questionnaire was structured. It was answered by a sample of 233 primary education teachers of the Region of Western Greece. Data was analyzed using the statistical software SPSS 26.0 for Windows. The results of the research show that teachers believe that students will have more opportunities to learn at different times and in different locations with tools tailored to their individual abilities and will choose the devices, programs and methods by which they will learn. In addition, the use of technology in education will improve learning outcomes, will help save material resources and improve teachers' communication with parents, students and education staff. However, participating teachers believe that the use of technology entails a greater workload for them, leads to the creation of unknown and demanding professions, leads to sharper inequalities and widens the social gap. In addition, there is a very high risk of job losses and is related to the feeling of insecurity and danger. At the same time, it raises moral issues, threatens individuality and the private sphere of life, homogenizes the views of people and polarizes societies. Finally, additional studies, employment, overall service and training in new technologies have a statistically significant effect on teachers' perceptions.

Keywords: $4^{\text {th }}$ Industrial revolution, Education 4.0, teachers, risks, benefits 


\section{Introduction}

Over the last years there have been dramatic changes in many areas of human life, as we are at the beginning of a new technological revolution, the fourth, which undoubtedly brings about rapid changes in the way people live, work, communicate and interact. Jack Ma (2016) argues that technological advances and industrial revolutions are related to both positive and negative elements. Both the first and the second Industrial Revolutions were followed by the two World Wars. In addition, the OECD (2018) states that "scientific knowledge creates opportunities and solutions, while fueling the disturbed waves of change in every field. Unprecedented innovation in science and technology ... raises fundamental questions about what is human" (Karanikola \& Panagiotopoulos, 2018, p.4).

These changes are inevitably rapid and often uncontrollable. We cannot be sure of their proper management, but we can, based on existing theoretical and research data, guess the actions we can take. According to the OECD (2018, pp. 3-4), education can make a difference if people embrace the challenges they face or if they overcome them. This will be achieved when it is not simply aimed at preparing young people for the world of work, but when equipping them with the skills they need to become active, responsible and committed citizens. The role of teachers, therefore, is crucial.

\section{Education and the 4th Industrial Revolution}

With the advent of the 4th Industrial Revolution, the role of education is changing and it is called to respond to the emerging needs. This brings us to the development of Education 4.0, a term used by theorists to describe the various ways in which technology is integrated into the educational space. According to Fisk (2017) and Asiz (2018), there are nine key dimensions contained in Education 4.0. Initially, learning, due to the available e-learning tools, can take place at any time and place. In addition, it acquires a personalized character by allowing students to choose for themselves the way in which they wish to learn. Also, students are more involved in the definition of the curriculum, in the design and implementation of work plans, while at the same time experiencing situations of practical and experiential learning, guidance and collaboration. In such a context, theory becomes practice, students become independent, think logically and lead to conclusions. Finally, the assessment does not follow the traditional models and is subject to significant variations depending on the context and the student.

What is the role of the teacher in the new work environment, that of Education 4.0 ? At a first level, teachers are the ones who will be called upon to manage the changes brought about by the 4th Industrial Revolution both personally and professionally. The term "Teacher 4.0" comes to meet the current requirements that the teacher has to manage in order to adopt new 
teaching methods and manage a virtual audience or a traditional classroom that may use smart augmented reality devices (Razak, Alakrash \& Sahboun, 2018).

Teachers no longer teach individually, but in collaboration with other teachers, the education staff, Parents and Guardians Associations, local authorities and agencies (Doucet, et al., 2018). Teachers themselves are lifelong learners and actively participate in their own education and training. They seek their professional growth and development in order to improve both students' learning and their own performance (Xing \& Marwala, 2017). Important indicators and basic prerequisites of teachers' readiness to manage change are the appropriate knowledge and skills but also the exploration of their perceptions, attitudes and beliefs about the new context, as dictated by rapid technological developments (Terrell \& Lindsey, 2009).

Basic personality traits (dispositions) that are extensively mentioned in the literature play an important role in handling changes are openness, empathy, flexibility and curiosity. In addition, educators need to have the experience, the ability to adapt to new technologies and global challenges. Old literacy based on reading, writing and mathematics must be strengthened by preparing new literacy, i.e. knowledge of data, utilization of technology and management of human resources (Aoun, 2018; Sudlow, 2018).

Additionally, Dinar Wahyuni (2018) refers to the ability to manage globalization, the ability of future strategies and counseling, but also the ability of teachers to be able to make a comprehensive assessment, present modules, according to the passion of students, and make innovative and authentic lessons (Xing, 2015).

Finally, they need to be tech-savvy, realize that inevitable change is not always a threat but possibly something progressive and positive. Creativity, one of the top skills of the 21st century citizen, is a structure, an approach, a method for solving problems (Wahyuni, 2018).

\section{Methodology of Research}

This study seeks to investigate and capture the attitudes of teachers towards the principles, benefits and risks of Education 4.0, as it is shaped in the context of the 4th Industrial Revolution. The review of the relevant literature indicates the lack of relevant research at national level. The quantitative methodology was followed and a questionnaire was completed by a total of 233 teachers of Primary Education of the Region of Western Greece. It was distributed via email in google forms.

The review of the literature and related research formed the basis for the construction of the questionnaire. It consists of two parts. The first part concerns the demographics of the participants, and includes seven (7) closedended questions concerning gender, age, additional studies, employment / 
relationship, years of service and level of Information and Communications Technology (ICT) training.

The second part deals with teachers' attitudes towards the principles, benefits and risks of Education 4.0 and includes a total of thirty-one five-point likert proposals. Eight of these questions examine the extent to which they agree or disagree on the basic principles of education in line with the needs of the 4th Industrial Revolution (technology and learning) and the twenty-three examine the extent to which they agree or disagree on the utilization of technology in education.

This questionnaire includes closed-ended questions, which are usually easily answered as they are predefined. They offer reliable and easily comparable answers, without the need for a time-consuming coding process. They also offer the opportunity to obtain information on topics that could hardly be obtained by another method (Grinnell \& Unrau, 2005).

\section{Data analysis and research reliability}

Data was analyzed using statistical software SPSS 26.0 for Windows. This was followed by the Kolmogorov-Smirnov normal distribution test (233> 50), the results of which showed an abnormal distribution of variables. Finally, a non-parametric Kruskal-Wallis $\mathrm{H}$ correlation test was performed in order to investigate the correlations with demographic data. Internal consistency and validity test (Cronbach's alpha) was performed (Table 1). The price showed satisfactory results (Cronbach's alpha: $>0.70$ and specifically 0.898 in total for both dimensions).

Table 1. Cronbach's Alpha

\begin{tabular}{llll}
\hline & Dimensions & $\begin{array}{l}\text { Number of } \\
\text { statements }\end{array}$ & $\begin{array}{l}\text { Cronbach's } \\
\text { Alpha }\end{array}$ \\
\hline \multirow{3}{*}{ Technology and attitudes } & Technology and learning & 8 & 0,931 \\
\cline { 2 - 4 } & Utilization of technology & 23 & 0,859 \\
\cline { 2 - 4 } & TOTAL & $\mathbf{3 1}$ & $\mathbf{0 , 8 9 1}$ \\
\hline
\end{tabular}

Regarding the demographics of the sample in terms of gender, $66.1 \%$ are women and $33.9 \%$ are men. Regarding age, $30.9 \%$ are $41-50$ years old, $27.5 \%$ are $51-55$ years old, $18.9 \%$ are $31-40$ years old, $14.6 \%$ are 56 and older and $8.2 \%$ are $22-30$ years old. In terms of additional studies, $34.3 \%$ have a master's degree, $4.3 \%$ have a doctorate, $8.2 \%$ have a second university degree, $14.2 \%$ have a bachelor's degree, $8.6 \%$ have postgraduate education / teaching while $30.5 \%$ state that they have done something else. Regarding the employment relationship, the majority $(74.2 \%)$ are permanent, $16.3 \%$ are temporary and $9.5 \%$ have a position of responsibility (Principals). Regarding the years of service, $33 \%$ are 26 years and older, $23.6 \%$ are $16-20$ years old, $17.2 \%$ are $11-15$ years old, $10 \%$ are $21-25$ years old, $8.2 \%$ have $6-10$ years 
and $7.7 \%$ have $0-5$ years of service. Regarding the level of studies in Information and Communication Technologies (ICT), $41.6 \%$ have the basic level accreditation ( $1^{\text {st }}$ grade), $48.1 \%$ have the advanced level accreditation ( $2^{\text {nd }}$ grade), $8.6 \%$ state something else, while $1,7 \%$ have no ICT accreditation at all.

Regarding technology and learning, the average value of the respondents' answers ranges from 3.3 (enough) to 3.6 (very much) with a total average value of 3.5 (very much). The teachers of the sample believe that with the use of technology students (3.5-3.6) will have many more opportunities to learn at different times and in different locations as well as will learn with tools tailored to their individual abilities.

Learning will be based a lot (3.5) on work plans / projects and field experiences, i.e. activities outside the classroom which will be relevant and complement the content of a lesson. The way students are assessed will change very radically (3.6) and the guidance provided by the teacher will become much (3.6) more and more important. Also, students will choose several (3.4) of the devices themselves (e.g. tablets, laptops, smartphones, e-book readers), the programs and the methods with which they will learn. Finally, students will participate more (3.3) more and more in shaping their curriculum.

Table 2. Distribution of answers for technology and learning

\begin{tabular}{|c|c|c|c|c|c|c|c|}
\hline & Not at all & Quite & Enough & Much & $\begin{array}{l}\text { Very } \\
\text { much }\end{array}$ & \multirow[t]{2}{*}{ Mean } & \multirow[t]{2}{*}{ S.D. } \\
\hline & \multicolumn{5}{|c|}{ Percentage \% } & & \\
\hline $\begin{array}{l}\text { 1. Students will have more } \\
\text { opportunities to learn at } \\
\text { different times and in different } \\
\text { locations. }\end{array}$ & 4,7 & 9,4 & 28,3 & 35,2 & 22,3 & 3,6 & 0,071 \\
\hline $\begin{array}{l}\text { 2. Students will learn with } \\
\text { tools tailored to their } \\
\text { individual abilities. }\end{array}$ & 6,9 & 11,6 & 28,8 & 33,9 & 18,9 & 3,5 & 0,074 \\
\hline $\begin{array}{l}\text { 3. Students will choose the } \\
\text { devices (e.g. tablet, laptop, } \\
\text { smartphone, e-book reader), } \\
\text { the programs and the methods } \\
\text { with which they will learn. }\end{array}$ & 8,2 & 14,6 & 28,3 & 30,9 & 18 & 3,4 & $\mathbf{0 , 0 7 7}$ \\
\hline $\begin{array}{l}\text { 4. Learning will be based on } \\
\text { project plans. }\end{array}$ & 6 & 13,3 & 26,2 & 38,6 & 15,9 & 3,5 & $\mathbf{0 , 0 7 2}$ \\
\hline $\begin{array}{l}\text { 5. Learning will also be based } \\
\text { on field experiences, i.e. } \\
\text { activities outside the } \\
\text { classroom which will be } \\
\text { relevant and complement the } \\
\text { content of a lesson. }\end{array}$ & 9,9 & 9 & 25,3 & 33,5 & 22,3 & 3,5 & $\mathbf{0 , 0 8}$ \\
\hline $\begin{array}{l}\text { 6The way students are } \\
\text { assessed will change radically. }\end{array}$ & 6 & 10,7 & 19,7 & 41,2 & 22,3 & 3,6 & 0,074 \\
\hline
\end{tabular}




\begin{tabular}{|c|c|c|c|c|c|c|c|}
\hline $\begin{array}{l}\text { 7. Students will be more and } \\
\text { more involved in shaping their } \\
\text { curriculum. }\end{array}$ & 9,9 & 15 & 29,6 & 31,3 & 14,2 & 3,3 & $\mathbf{0 , 0 7 7}$ \\
\hline $\begin{array}{l}\text { 8. The guidance provided by } \\
\text { the teacher will become more } \\
\text { and more important. }\end{array}$ & 3,9 & 16,3 & 17,6 & 41,6 & 20,6 & 3,6 & $\mathbf{0 , 0 7 2}$ \\
\hline TOTAL & & & & & & 3,5 & 0,061 \\
\hline Cronbach's Alpha & $\mathbf{0 , 9 3 1}$ & & & & & & \\
\hline
\end{tabular}

Regarding the utilization and use of technology in education, the average value of the answers of the participating teachers ranges from 3.0 (enough) to 4.1 (very much) with a total value of 3.7 (very much). Utilizing technology in education a lot (3.5-4.0) will benefit students, teachers and principals, will be associated with increasing the efficiency of the school unit and with better learning outcomes as well as will make the lesson more interesting and attractive for students while at the same time it will contribute a lot (3.6) to the saving of material resources. Also, the use of technology will contribute significantly (3.0-3.4) to the improvement of teachers' communication with students, parents and educators.

The utilization of technology in education implies a much (3.8) greater workload for teachers, it will bring a lot (3.9) of greater aggravation of inequalities. In addition, the use of technology is very much (3.7) associated with job losses, raises many (3.8) ethical issues, leads a lot (4.0) to the creation of different and demanding professions. It can greatly widen (3.9) the social divide, allow too much (4.0) to spread false news and greatly threaten (3.8) individuality and the private sphere of life. Then, the use of technology is quite (3.4) associated with the feeling of insecurity and danger, gives enough (3.4) voice in cyberbullying and hate speech, makes the world quite (3.3) more complicated, unstable and uncertain. Finally, technology quite homogenizes (3.4) the views of people and polarizes societies.

Table 3. Distribution of answers for the utilization of technology

\begin{tabular}{|c|c|c|c|c|c|c|c|}
\hline & Not at all & Quite & Enough & Much & $\begin{array}{l}\text { Very } \\
\text { much }\end{array}$ & \multirow[t]{2}{*}{ Mean } & \multirow[t]{2}{*}{ S.D. } \\
\hline & \multicolumn{5}{|c|}{ Percentage \% } & & \\
\hline $\begin{array}{l}\text { 1. Utilizing technology in } \\
\text { education benefits students. }\end{array}$ & 0,9 & 7,3 & 20,6 & 44,6 & 26,6 & 3,9 & 0,06 \\
\hline $\begin{array}{lll}\text { 2. Utilizing technology } & \text { in } \\
\text { education benefits teachers. } & \\
\end{array}$ & 1,3 & 11,6 & 10,7 & 48,5 & 27,9 & 3,9 & 0,064 \\
\hline $\begin{array}{lcc}\text { 3. } & \text { Utilizing technology } & \text { in } \\
\text { education benefits principals. } & \\
\end{array}$ & 2,1 & 6,9 & 14,2 & 46,4 & 30,5 & 4,0 & 0,063 \\
\hline $\begin{array}{l}\text { 4. The use of technology in } \\
\text { education is associated with } \\
\text { increasing the efficiency of the } \\
\text { school unit. }\end{array}$ & 3,9 & 10,3 & 23,6 & 40,3 & 21,9 & 3,7 & 0,069 \\
\hline
\end{tabular}


5. Utilization of technology in education is associated with better learning outcomes.

$\begin{array}{lllllll}6,0 & 9,4 & 27,9 & 40,3 & 16,3 & \mathbf{3 , 5} & \mathbf{0 , 0 7}\end{array}$

6. Utilizing technology in education helps to save material resources.

4,3

$12,9 \quad 26,2$

35,6

21,0

3,6

0,071

7. Utilizing technology in

education helps to improve teachers' communication with

6,4

$16,7 \quad 23,6$

33,5

$19,7 \quad 3,4$

$\mathbf{0 , 0 7 7}$

parents.

8. The use of technology in education helps to improve the communication of teachers with

14,6

$22,3 \quad 27,9$

$23,2 \quad 12,0$

3,0

0,081

students.

9. Utilizing technology in education helps to improve teachers' communication with 6,9 18,9 22,3 35,6 16,3 $3,4 \quad 0,076$ education executives.

10. The use of technology in education makes the lesson more interesting and attractive to $3,0 \quad 7,7$ $18,9 \quad 35,6 \quad 34,8$ 3,9 0,069 students.

11. The use of technology in education implies a greater workload for teachers.

12. The use of technology in education exacerbates $\quad 5,2$

$4,7 \quad 6,4$
20,2 37,3 31,3 3,8 $\mathbf{0 , 0 7 1}$ inequalities.

$5,2 \quad 9,4$

$15,5 \quad 29,2 \quad 40,8$

3,9

0,078

13. The use of technology in education is associated with job losses.

14. The use of technology raises ethical issues.

$7,3 \quad 11,2$

$18,5 \quad 27,5 \quad 35,6$

3,7

0,082

$7,7 \quad 6,0$

$21 \quad 30,9$

34,3

3,8

$\mathbf{0 , 0 7 9}$

15. The use of technology is associated with feelings of 11,6 12,9 insecurity and danger.

16. The use of technology leads to the creation of differen professions.

17. The use of technology leads to the creation of demanding professions.

\begin{tabular}{lllllllll}
\hline $\begin{array}{l}\text { 18. Technology can widen the } \\
\text { social divide. }\end{array}$ & 4,3 & 8,2 & 17,2 & 36,5 & 33,9 & $\mathbf{3 , 9}$ & $\mathbf{0 , 0 7 2}$ \\
\hline $\begin{array}{l}\text { 19. Technology gives voice to } \\
\text { cyberbullying and hate speech. }\end{array}$ & 6,4 & 13,7 & 30,9 & 32,2 & 16,7 & $\mathbf{3 , 4}$ & $\mathbf{0 , 0 7 3}$ \\
\hline $\begin{array}{l}\mathbf{2 0} \text {. Technology allows the spread } \\
\text { of fake news. }\end{array}$ & 3,0 & 5,6 & 16,3 & 37,8 & 37,3 & $\mathbf{4 , 0}$ & $\mathbf{0 , 0 6 7}$ \\
\hline
\end{tabular}




\begin{tabular}{|c|c|c|c|c|c|c|c|}
\hline $\begin{array}{l}\text { 21. Technology makes the world } \\
\text { more complex, unstable and } \\
\text { uncertain. }\end{array}$ & 8,2 & 16,7 & 26,2 & 32,2 & 16,7 & 3,3 & $\mathbf{0 , 0 7 7}$ \\
\hline $\begin{array}{l}\text { 22. The use of technology } \\
\text { threatens individuality and the } \\
\text { private sphere of life. }\end{array}$ & 3,4 & 11,6 & 18,9 & 33,5 & 32,6 & 3,8 & $\mathbf{0 , 0 7 3}$ \\
\hline $\begin{array}{l}\text { 23. Technology homogenizes } \\
\text { people's views and polarizes } \\
\text { societies. }\end{array}$ & 5,6 & 16,7 & 30,0 & 30,0 & 17,6 & 3,4 & $\mathbf{0 , 0 7 4}$ \\
\hline TOTAL & & & & & & 3,7 & $\mathbf{0 , 0 3 6}$ \\
\hline Cronbach's Alpha & $\mathbf{0 , 8 5 9}$ & & & & & & \\
\hline
\end{tabular}

\section{Correlations with demographics}

In order to check the gender correlation of the participants with their answers about Technology and attitudes (Technology and learning, Technology utilization) a non-parametric Kruskal-Wallis H correlation test was performed, with a statistical significance level $\alpha=0.05$ (5\%), meaning that there are no statistically significant differences.

Regarding age correlation, there are statistically significant differences with the utilization of technology $(\mathrm{x} 2(4)=10,539, \mathrm{p}=0.032<0.05)$. The Mann-Whitney U meta-test (Table 4) for age comparison shows that statistically significant differences are found between the categories: a) "22$30 "$ and "31-40" $(\mathrm{U}(19,44)=255,500, \mathrm{p}=0.015<0.05), \mathrm{b})$ "22-30" and "41$50 "(\mathrm{U}(19,72)=454,000, \mathrm{p}=0.024<0.05)$ and c) "22-30" and "51-55" (U $(19,72)=343,000, p=0.004<0.05)$. Those who belong to the age group "2030 " years use to a greater extent (mean rank $=40.55)$ technologies than those who are aged "31-40" years (mean rank $=28.31$ ), to a greater degree (mean rank $=58.11)$ in relation to those aged "41-50" (mean rank $=42.81)$ and to a greater extent (mean rank $=55.95)$ compared to those aged "51-55" (mean rank $=37.86$. The highest degree (mean rank $=58.11$ ) of technology utilization is found at the age of "22-30" years and the lowest degree (mean rank = 28.31) at the age of "31-40" years.

Table 5. Correlations with age

\begin{tabular}{llllll}
\hline & Age & N & Mean rank & $\begin{array}{l}\text { Mann- } \\
\text { Whitney U }\end{array}$ & $\begin{array}{l}\text { p- } \\
\text { value }\end{array}$ \\
\hline \multirow{4}{*}{ Utilization of technology } & $22-30$ & 19 & 40,55 & 255,500 & 0,015 \\
\cline { 2 - 5 } & $22-40$ & 44 & 28,31 & & \\
& $41-50$ & 72 & 42,81 & 454,000 & 0,024 \\
\cline { 2 - 5 } & $22-30$ & 19 & 55,95 & \multirow{2}{*}{343,000} & 0,004 \\
\hline
\end{tabular}

Checking the correlation of additional studies shows that there are statistically significant differences with Technology and learning $\left(\chi^{2}(4)=\right.$ 
$19,871, \mathrm{p}=0,001<0.05)$. The Mann-Whitney U post-test shows that those with a second undergraduate degree agree less (mean rank $=29.95$ ) on the positive relationship between technology and learning than those with a Postgraduate Diploma (mean rank $=54.76)$ and less (mean rank $=14.05)$ in relation to those who do Postgraduate Education (mean rank $=25.65$ ). The highest grade (mean rank $=54.76$ ) for Technology and learning is located in those who have a Master's degree and the lowest grade (mean rank $=14.05$ ) in those who have a second undergraduate degree from a university / technical institute.

The control of the correlation of the employment relationship of the teachers of the sample, shows that there are statistically significant differences with the Utilization of technology $\left(x^{2}(2)=6,241, \mathrm{p}=0.044<0.05\right)$. The Mann-Whitney U meta-test (Table 6) shows that Principals are more (mean rank $=123.64$ ) positive in the use of technology in education compared to those who are deputy teachers (mean rank $=94.74$ ). The highest degree in Familiarity with software and social media is observed in those who are deputy teachers (mean rank $=128.87)$ and the lowest degree (mean rank $=94.74)$ in those who are permanent in Technology Utilization.

Table 6. Employment correlations

\begin{tabular}{|c|c|c|c|c|c|c|}
\hline & & $\begin{array}{l}\text { Employment } \\
\text { relationship }\end{array}$ & $\mathbf{N}$ & Mean rank & $\begin{array}{l}\text { Mann- } \\
\text { Whitney U }\end{array}$ & $\begin{array}{l}\text { p- } \\
\text { value }\end{array}$ \\
\hline $\begin{array}{l}\text { Utilization } \\
\text { technology }\end{array}$ & of & $\begin{array}{l}\text { Permanent } \\
\text { Principal }\end{array}$ & $\begin{array}{l}173 \\
22\end{array}$ & $\begin{array}{l}94,74 \\
123,64\end{array}$ & 1339,000 & 0,024 \\
\hline
\end{tabular}

The control of the correlation of the years of total service of the teachers of the sample, also shows that there are statistically significant differences with the Utilization of technology $\left(x^{2}(4)=11,737, \mathrm{p}=0.039\right.$ $<0.05)$. The Mann-Whitney U meta-test (Table 7) shows that those with "0-5" years of total service are (mean rank $=24.92$ ) more positive in technology utilization in education than with those who have "6-10" years of total service (mean rank $=13.39$ ), more (mean rank $=38.53)$ than those who have "11-15" years (mean rank $=25.44)$, more (mean rank $=46.08$ ) compared to those who have "16-20" years (mean rank $=34.03)$ and more $($ mean rank $=61.25)$ compared to those who have "26 and over" years of total service (mean rank $=44.90)$. The highest degree in the Utilization of technology is located at the age of "0-5" years (mean rank $=61.25$ ) and the lowest degree (mean rank $=$ 13.39) at the age of "6-10" years of total service. 
Table 7. Correlations with years of total service

\begin{tabular}{|c|c|c|c|c|c|c|}
\hline & & Years of service & $\mathbf{N}$ & Mean rank & $\begin{array}{l}\text { Mann- } \\
\text { Whitney U }\end{array}$ & p-value \\
\hline \multirow{8}{*}{$\begin{array}{l}\text { Utilization } \\
\text { technology }\end{array}$} & \multirow{8}{*}{ of } & $0-5$ & 18 & 24,92 & \multirow{2}{*}{64,500} & \multirow{2}{*}{0,001} \\
\hline & & $6-10$ & 19 & 13,39 & & \\
\hline & & $0-5$ & 18 & 38,53 & \multirow{2}{*}{197,500} & \multirow{2}{*}{0,006} \\
\hline & & $11-15$ & 40 & 25,44 & & \\
\hline & & $0-5$ & 18 & 46,08 & \multirow{2}{*}{331,500} & \multirow{2}{*}{0,036} \\
\hline & & $16-20$ & 55 & 34,03 & & \\
\hline & & $0-5$ & 18 & 61,25 & \multirow{2}{*}{454,500} & \multirow{2}{*}{0,023} \\
\hline & & 26 and over & 77 & 44,90 & & \\
\hline
\end{tabular}

Finally, the control of the correlation of Training in the technologies of the sample teachers demonstrates that there are no statistically significant differences between groups having different years of total service with Technology and attitudes (Technology and learning, Technology utilization).

\section{Discussion}

The fourth industrial revolution can affect society and the economy in various ways (World Economic Forum, 2018). Research participants believe that to a great extent students will have more opportunities to learn at different times and in different locations with tools tailored to their individual abilities. Also, they will choose their learning devices and programs and they will be more and more involved in shaping the program. The guidance provided by the teacher will acquire to a great extent more and more weight.These findings are consistent with the views of Bayne (2015) and Ng'ambi et al. (2016), according to which new forms of emerging technology facilitate learning based on students' skills and increase the variety and speed of learning provided. Also, Beetham and Sharpe (2013) believe that digital technology facilitates and increases interactions between teachers and students and transforms teaching and the learning process. Finally, according to the European Commission research (2019), teachers agree with the fact that the use of ICT in teaching and learning has a positive effect on the performance, motivation and development of students' transversal skills (critical thinking, analysis, problem solving, social skills).

Regarding the utilization of technology in education, the participants believe that it will greatly benefit students, teachers, principals and it will increase the efficiency of the school unit. The use of technology will make the lesson very interesting and attractive to students. It will also contribute greatly to the saving of material resources and to a large extent will contribute to the improvement of teachers' communication with parents, students and education staff. 
Regarding the risks and dangers posed by the new reality, the research revealed the following: Initially, according to the perceptions of the teachers of the sample regarding the utilization and use of technology in education and the learning process, their attitude is very positive. This finding is consistent with the findings of Ertmer et al. (2012), Al-Zaidiyeen, Mei and Fook (2010) and the European Commission (2019), where teachers are open and have a positive attitude towards the use of technology in learning and teaching.

However, the participating teachers believe that the use of technology implies a much greater workload for teachers. The use of technology leads to a great extent to the creation of different and demanding professions. It exacerbates inequalities and widens the social gap. There is a very high risk of job losses. At the same time, it raises a lot of ethical issues. It gives enough voice to cyberbullying and hate speech, making the world more complicated, unstable and uncertain. In addition, the use of technology threatens to a great extent the individuality and the private sphere of life and homogenizes to a large extent the views of people and greatly polarizes societies.

These findings are consistent with the views of Waidner and Kasper (2016), according to whom the increased use of data analysis is likely to bring about new challenges in matters of security, privacy and personal data protection as a major source of concern. As Manda and Backhouse (2016) characteristically report, the "smart" age of technology highlights issues of trust in privacy and security. Similar findings have been highlighted by the research of Solomonidou (2002), Tsoutsa and Kedraka (2013), which highlight the insecurity of teachers regarding the use of technology in teaching due to lack of necessary equipment, time-consuming finding or production of educational material, lack of technical support and lack of support from their colleagues. Finally, Legontis (2010) research on science teachers showed that the integration of technology in teaching takes more time.

Finally, regarding the correlations of demographic characteristics (gender, age, additional studies, employment relationship, total service, and ICT training) of the sample teachers, statistically significant differences are demonstrated for the utilization of technology in education. Those who are younger (22-30 years old) are more positive in the use of technology in education than those who are older (31-40, 41-50, 51-55). However, a study by Summak, Bağlıbel and Samancioğlu (2010) that assessed the technological readiness of primary school teachers in Turkey showed that there is no significant difference between technological readiness and the age of teachers. Those who have additional studies (postgraduate diploma, postgraduate education) are more positive about the usefulness of technology in learning than those who have a second degree. Also, the permanent staff is to a lesser extent positive in the utilization of technology in learning compared to the Principals. Statistically significant differences are recorded regarding the 
years of total service of the respondents. Those who have fewer (0-5) years of total service are more positive in utilizing technology in education compared to those who have more years of total service (6-10, 11-15, 16-20 and 26 and over).

\section{Conclusion}

The present study highlighted important dimensions of the 4th Industrial Revolution, which drastically affect the way people live, work, govern and interact. The context of the 4th Industrial Revolution undoubtedly affects the field of education, where emerging digital technologies are coming to transform education and the current role of the teacher. Future education systems will be judged by whether and how well they prepare students to function in the world of the 21st century, a world that will require a rich digital profile with skills in artificial intelligence, robotics, the Internet of Things, augmented reality, virtual reality, 3D printing, smart factories, etc. (Bezuidenhout, 2018).

The new role of the teacher in the classroom of the 21st century, in the context of "Education 4.0" requires changes in their knowledge, skills and attitudes. The teacher must know how to act as a class mediator, how to create a positive, supportive and safe learning environment for all students, how to set long-term and short-term goals, how to encourage students' curiosity, how to communicate effectively, how to use technology (Xing, 2015), how to prepare specialized and trained professionals to work in a global and digital environment.

In terms of management, Education 4.0 contributes to better school organization, reduced management costs and the implementation of more efficient business models (Lase, 2019; Working Document E2030: Education and Skills for the 21st Century January, 2017).

The research data of the present study demonstrate the positive attitude of most of the participants towards technology and the benefits of Education 4.0 for all those involved in education the answers of the participating teachers (the average value ranges from 3.0 (enough) to 4.1 (very much) with a total value of 3.7 (very much): better communication, improved learning, flexible, comprehensive and open curricula, personalized teaching, learning without space and time, utilization of many platforms, various online learning tools harmonized at the individual pace of each, opportunities for distance learning.

In such a context, teachers play a key role. Their initial education, however, needs to be strengthened and redefined through the process of lifelong learning. Of course, digital skills alone are not enough. They must coexist with superior and more complex skills, the construction of which can contribute to the development and enhancement of self-confidence and personal performance (Zinnbauer, 2007). 
In conclusion, the present research through its findings, as reflected in the perceptions of the teachers of the sample, hopes to contribute with any of its limitations to a further understanding of the educational reality and to highlight the possibilities and necessity of school operation in the new digital environment.

In addition, and given that no other similar research has been conducted based on this questionnaire and in this area it should be a cause for fruitful dialogue, reflection and further research. At the same time, to act as a stimulus for the orientation of the transformation of the school but also the initiatives that the official state should take for the creation of conditions for successful implementation.

\section{References:}

1. Attride-Stirling, J. (2001). "Thematic Networks: an Analytic Tool for Qualitative Research". Qualitative Research Copyright, I (3), 385405. https://doi.org/10.1177/146879410100100307

2. Al-Zaidiyeen, N.J., Mei, L.L., \& Fook, F.S. (2010). "Teachers' attitudes and levels of technology use in classrooms: The case of Jordan schools". International Educational Studies, 3(2), 211-218.

3. Aoun, J. E. (2018). "Robot-proof: higher education in the age of artificial intelligence". Journal of Education for Teaching. https://doi.org/10.1080/ 02607476.2018.1500792

4. Aziz, H. A. (2018). "Education 4.0 Made Simple: Ideas For Teaching". International Journal of Education and Literacy Studies, 6. https://doi.org/10.7575/aiac.ijels.v.6n.

5. Bayne, S. (2015). "What's the matter with 'technology-enhanced learning'?" Learning Media Technology, 40, 5-20.

6. Beetham, H. \& Sharpe, R. (2013). Rethinking Pedagogy for a Digital Age: Designing for 21st Century Learning; Apollon, UK: Routledge.

7. Bezuidenhout, A. (2018). "Analysing the importance-competence gap of distance educators with the increased utilisation of online learning strategies in a developing world context". International Review of Research in Open and Distributed Learning, 19(3), 264-281. https://doi.org/10.19173/irrodl.v19i3.3585

8. Doucet, A., Evers, J., Guerra, E., Lopez, N., Soskil, M., \& Timmers, K. (2018). Teaching in the fourth industrial revolution: Standing at the precipice.

https://www.researchgate.net/publication/324795822_Teaching_in_th e_fourth_industrial_revolution_Standing_at_the_precipice

9. Ertmer, P. A., Ottenbreit-Leftwich, A. T., Sadik, O., Sendurur, E. \& Sendurur, P. (2012). "Teacher beliefs and technology integration 
practices: A critical relationship". Computers \& Education, 59(2), 423-435.

10. European Commission. (2019). Final Report. 2nd Survey of Schools: ICT in Education Objective 1: Benchmark progress in ICT in schools. Luxembourg: Publications Office of the European Union.

11. Fisk, P. (2017). Education 4.0.. the future of learning will be dramatically different, in school and throughout life. http://www.thegeniusworks.com/2017/01/future-education-youngeveryone-taught-together

12. Grinnell, R.M. \& Unrau, Y.A. (2005). Social Work Research and Evaluation: Quantitative and Qualitative Approaches. New York: Oxford University Press.

13. Karanikola, Z., \& Panagiotopoulos, G. (2018). "4th Industrial revolution: the challenge of changing human resources skills". European Journal of Training and Development Studies, 5 (3), 1-7.

14. Legontis, A. (2015). The training of teachers in the Training Support Centers (K.S.E.) and in the University Training Centers (PAKE) in the utilization of ICT in the educational and teaching process. Doctoral thesis. Thessaloniki: University of Macedonia.

15. Ma, J. (2016). What is the $4^{\text {th }}$ Industrial Revolution? World Economic Forum.

https://www.youtube.com/watch?v=kpW9JcWxKq0\&list=RDCMUC w-kH-Od73XDAt7qtH9uBYA\&index $=23$

16. Manda, M. I. \& Backhouse, J. (2016) Addressing trust, security and privacy concerns in e-government integration, interoperability and information sharing through policy: a case of South Africa. Proceedings of the 2016 International Conference on Information Resources Management (CONF-IRM). Paper 67. https://aisel.aisnet.org/confirm2016/67.

17. Ng'ambi, D., Brown, C., Bozalek, V., Gachago, D. \& Wood, D. (2016). "Technology enhanced teaching and learning in South African higher education-A rearview of a 20 year journey". Br. J. Educ. Technology, 47, 843-858.

18. OECD. (2018). Education for a Bright Future in Greece, Reviews of National Policies for Education. Paris: OECD Publishing. http://dx.doi.org/10.1787/9789264298750-en

19. Razak, N., Alakrash, H., \& Sahboun, Y. (2018). "English language teachers' readiness for the application of technology towards fourth industrial revolution demands". Asia-Pacific Journal of Information Technology and Multimedia, 7 (2-2), 89 - 98.

20. Solomonidou, Ch. (2002). Collaborative Learning with the Use of ICT: Experiences from Primary Schools of Thessaly. In Dimitrakopoulou 
A. (Ed.), Information and Communication Technologies in Education. Proceedings of the 3rd Panhellenic Conference with international participation, Volume: A ', 325-334. Athens: Kastaniotis.

21. Sudlow, B. (2018). Review of Joseph E. Aoun (2017). "Robot Proof: Higher Education in the Age of Artificial Intelligence". Postdigital Science and Education. https://doi.org/10.1007/ s42438-018-0005-8

22. Sumak, B., Pusnik, M. ve Hericko, M. (2014). An Empirical Study of Factors Affecting the Adoption of Self-Service Checkout Terminals in Slovenia. International Convention on Information and Communication Technology, Electronics and Microelectronics (MIPRO). Opatija, Croatia.

23. Terrell, R.D., \& Lindsey, R.B. (2009). Culturally Proficient Leadership: The Personal Journey Begins Within. Corwin Press.

24. Tsoutsa, S. \& Kedraka, K. (2013). "Factors influencing philologists in the pedagogical utilization of ICT after their training in new technologies by specialty: the case of the philologists of Kavalas Prefecture". Educational Cycle, 1, (2), 93-110.

25. Wahyuni, D. (2018). Peningkatan Kompetensi Guru Menuju Era Revolusi Industri 4.0. Info Singkat - Pusat Penelitian Badan Keahlian DPR RI.

26. Waidner, M., \& Kasper, M. (2016). Security In Industrie 4.0challenges and solutions for the fourth industrial revolution, Design, Automation \& Test in Europe Conference \& Exhibition, 1303-1308.

27. World Economic Forum. (2018). The future of Jobs Report. https://www.weforum.org/reports/the-future-of-jobs-report-2018

28. Xing, B. (2015). Massive online open course assisted mechatronics learning a hybrid approach". Furthering Higher Education Possibilities through Massive Open Online Courses, 245- 268.

29. Xing, B., \& Marwala, T. (2017).Implications of the Fourth Industrial Age on Higher Education". arXiv preprint arXiv:1703.09643, 197207.

30. Zinnbauer, D. (2007). What can Social Capital and ICT do for Inclusion? European Commission, Directorate-General Joint Research Centre, Institute for Prospective Technological Studies. http://ftp.jrc.es/EURdoc/eur22673en.pdf 